\title{
Biomass production from Bacillus sp. RAB9 using several carbon sources
}

\author{
Cívita Sousa, Bruno Klainer, Karine Lima*, Gustavo Pinto \\ From 5th Congress of the Brazilian Biotechnology Society (SBBIOTEC) \\ Florianópolis, Brazil. 10-14 November 2013
}

\section{Background}

The NYD medium (glucose, meat extract, yeast extract and peptone) is used for biomass production of some bacteria species that promote plant species growth [1-3]. The main carbon source present in this medium is the glucose that contributes a percentage of $25 \%$ to the medium price. An alternative to obtain a more accessible price for the medium is to replace the glucose by sources of lower cost. Several byproducts and feedstock from food industry and agro industry have been applied on microorganisms growth due your high availability and low cost. Among these, the molasses stands out as culture medium in fermentative processes because of your high contents of sugars, nitrogen and vitamins [4]. This study evaluated the replacement of glucose by comercial sucrose, soy molasses and sugar cane molasses seeking better conditions for biomass production from Bacillus sp. RAB9.

\section{Methods}

In this study was used the strain of Bacillus sp. RAB9. The assays were performed in $250 \mathrm{ml}$ flasks with $100 \mathrm{ml}$ of medium and incubated at $30^{\circ} \mathrm{C}$ on an orbital shaker at 150 $\mathrm{rpm}$. The biomass was quantified between 4 and 24 hours. The sugar content in each molasses was determined spectrophotometrically by the DNS method. The biomass was quantified from the absorbance $(600 \mathrm{~nm})$ of the medium after centrifugation at $3500 \mathrm{rpm}$ for $15 \mathrm{~min}$ using pre defined standard curves. A volume of $0.01 \mathrm{~g} . \mathrm{L}^{-1}$ of inoculum, calculated according the standard curves, was inoculated in the fermentation medium. The NYD medium has the following composition $\left(\mathrm{g} . \mathrm{L}^{-1}\right)$ : glucose 10.0; yeast extract 5.0; meat extract 3.0; peptone 5.0; $\mathrm{pH}$ 6.5. Tested: sucrose 10.0; soy molasses 10.0; sugar cane molasses 10.0.

\section{Results and conclusions}

In NYD medium the production biomass was 0.74 g. $\mathrm{L}^{-1}$ in 24 hours of fermentation. The results found showed an increase on lineage growth of $39.2 \%$ for sucrose, $\mathbf{9 5 . 9 \%}$ for soy molasses and $310.8 \%$ for sugar cane molasses. The replacement by cane molasses contributed to a $76.7 \%$ reduction in biomass cost. Selected the sugar cane molasses to replace the glucose in NYD medium was evaluated the concentrations of 10 to $20 \mathrm{~g}$. $\mathrm{L}^{-1}$ for choose the best concentration for replacement and subsequently the best temperature of 30 to $45^{\circ} \mathrm{C}$. The increase on cane molasses concentration did not contribute for the gain on biomass. Was observed that the best alternative to substitute glucose is the sugar cane molasses on concentration of 10 g. $\mathrm{L}^{-1}$ at $40^{\circ} \mathrm{C}$.

Published: 1 October 2014

References

1. Santos ER, Gouveia ER, Mariano RLR, Souto-maior AM: Controle biológico da mancha-aquosa do melão por compostos bioativos produzidos por Bacillus spp. Summa Phytopathology 2006, 32(4):376-378.

2. Peixoto AR, Mariano RLR, Moreira JOT, Viana IO: Hospedeiros alternativos de Xanthomonas campestris pv. viticola. Fitopatologia Brasileira 2007, 32(2):161-164.

3. Felix KCS, Souza EB, Michereff SJ, Mariano RLR: Survival of Ralstonia solanacearum in infected tissues of Capsicum annuum and in soils of the state of Pernambuco. Phytoparasitica 2012, 40:53-62.

4. Hauly COM, Oliveira AR, Oliveira AS: Produção de ácido lático por Lactobacillus curvatus em melaço de cana-de-açúcar. Semina: Ciências Agrárias 2003, 24(1):133-142.

doi:10.1186/1753-6561-8-S4-P172

Cite this article as: Sousa et al:: Biomass production from Bacillus sp. RAB9 using several carbon sources. BMC Proceedings 2014 8(Suppl 4): P172. 